\title{
MENINGKATKAN MOTIVASI BELAJAR SISWA MELALUI LEARNING COMMUNITY
}

\author{
Oleh: \\ Hasrat Aimang \\ Staf Pengajar Fakultas Keguruan dan Ilmu Pendidikan \\ Universitas Muhammadiyah Luwuk \\ hasrat@unismuhluwuk.ac.id
}

\begin{abstract}
Abstrak
Penelitian ini bertujuan untuk mendapatkan keterangan motivasi belajar siswa melalui learning community. Penelitian ini dilakukan MIN Kilongan Permai, Luwuk bulan Agustus sampai dengan Desember 2014. Jenis penelitian yang digunakan dalam penelitian ini adalah penelitian deskriptif. Berdasarkan hasil penelitian menunjukkan bahwa belajar adalah suatu bentuk perubahan dalam diri seseorang yang dinyatakan dalam cara-cara bertingkah laku yang baru berkat pengalaman dan latihan. Tujuan pembelajaran yang diinginkan tentu yang optimal agar dapat mencapai prestasi belajar dengan baik. Untuk itu, metode pembelajaran adalah salah satu hal yang perlu diperhatikan pendidik. Salah satu metode tersebut adalah metode Learning Community atau kelompok belajar.
\end{abstract}

Kata kunci : motivasi, learning community

\section{PENDAHULUAN}

Belajar adalah suatu hal yang tak pernah dapat dipisahkan dari setiap individu. Manusia diberi fasilitas berupa akal agar dimanfaatkan sebaik mungkin, yang salah satu caranya adalah dengan belajar. Ketika keinginan untuk belajar telah muncul sebagai suatu stimulus untuk mengetahui suatu hal, maka seseorang dengan keinginan belajar tadi akan memperoleh suatu hazanah keilmuwan. Disinilah peran motivasi berlangsung.

Pendidikan merupakan kebutuhan sepanjang hayat. Setiap manusia membutuhkan pendidikan, sampai kapan dan dimanapun ia berada. Pendidikan sangat penting artinya, sebab tanpa pendidikan manusia akan sulit berkembang dan bahkan akan terbelakang. Pendidikan adalah usaha sadar dan bertujuan untuk mengembangkan kualitas (Djamarah, 2005:22). Adapun pengertian pendidikan menurut Undang-Undang Sistem Pendidikan Nasional No.20 Tahun 2003 adalah usaha sadar dan terencana untuk mewujudkan suasana belajar dan proses pembelajaran agar peserta didik secara aktif mengembangkan potensi dirinya untuk memiliki kekuatan spiritual keagamaan, pengendalian diri, kepribadian, kecerdasan, ahlaq mulia, serta ketrampilan yang diperlukan dirinya, masyarakat, bangsa dan negara. Dengan pendidikan diharapkan manusia mengetahui akan segala kelebihannya yang dipotensikan untuk kualitas hidup lebih baek dari sebelumnya. 
Teori belajar menekankan bahwa belajar terdiri atas pembangkitan respon dengan stimulus yang pada mulanya bersifat netral atau tidak memadai (Hamalik, 2004:49). Tujuan pembelajaran merupakan salah satu aspek yang perlu dipertimbangkan dalam merencanakan pembelajaran, sebab segala kegiatan pembelajaran muaranya pada tercapainya tujuan tersebut. Oleh karena itu diperlukan keterampilan memilih dan menggunakan metode mengajar untuk diterapkan dalam sistem pembelajaran yang efektif sehingga hal ini akan membawa siswa kedalam situasi belajar yang bervariasi dan siswa terhindar dari situasi pembelajaran yang membosankan.

Berdasarkan penjelasan diatas, maka dapat disimpulkan bahwa belajar adalah suatu proses usaha yang dilakukan seseorang untuk memperoleh suatu perubahan tingkah laku yang baru secara keseluruhan, sebagai hasil pengalamannya sendiri dalam interaksi dengan lingkungannya serta membutuhkan stimulus untuk membangkitkan respon atau semangat belajar dengan menggunakan strategi-strategi belajar yang tepat.

Pada dasarnya motivasi adalah dorongan dasar yang menggerakkan seseorang bertingkah laku. Dorongan ini berada pada diri seseorang yang menggerakkan untuk melakukan sesuatu yang sesuai dengan dorongan dalam dirinya. Oleh karena itu, perbuatan seseorang didasarkan atas motivasi tertentu mengandung tema sesuai dengan motivasi yang mendasarinya. Dorongan yang bisa disebut sebagai motivasi ini juga berlaku utamanya dalam kegiatan belajar.

Dalam kegiatan belajar, motivasi sangat berperan penting agar tujuan yang ingin dicapai jelas yang kemudian akan mengantarkan seorang individu untuk melakukan kegiatan-kegiatan yang dibutuhkan demi mencapai apa yang telah menjadi misi dalam belajarnya. Seseorang dengan kesadaran dan motivasi yang tinggi dalam proses belajarnya akan memperoleh hasil yang berbeda dengan orang yang hanya belajar karena dorongan atau paksaan dari pihak tertentu.

Kebutuhan akan motivasi sangat urgen terutama dalam hal belajar. Karena pada dasarnya dengan belajar inilah individu akan mendapatkan segala hal yang dibutuhkan untuk menyonsong kehidupan mendatang. Seperti yang dikutip oleh Imam Syafi'i dalam suatu hadits berikut ini. "Barangsiapa menginginkan sukses dunia hendaklah diraihnya dengan ilmu dan barangsiapa menghendaki sukses akherat hendaklah diraihnya dengan ilmu, barangsiapa ingin sukses dunia akherat hendaklah diraih dengan ilmu."

Kian hari motivasi semakin dibutuhkan dalam melaksanakan kegiatan seharihari. Mengingat kemajuan teknologi yang dari hari ke hari semakin berkembang pesat membutuhkan generasi sekarang sebagai penerus bangsa harus memiliki keinginan yang kuat agar dapat bertahan hidup dengan tetap mengikuti dinamika kehidupan. Tetapi pada kenyataannya tidak sedikit masyarakat yang masih saja belum memiliki suatu visi atau misi kehidupan, terutama dalam hal belajar. Hal ini dikarenakan rendahnya potensi motivasi yang tertanam dalam jiwa seorang individu.

Dalam meningkatkan motivasi belajar siswa seorang guru mempunyai andil didalamnya yang mana memberikan suatu arahan untuk dapat bagaimana meningkatkan 
prestasi belajar siswa. Bagaimana untuk dapat meningkatkan prestasi belajar? Salah satu bentuk untuk meningkatkan prestasi belajar yaitu dengan memberikan motivasi belajar kepada siswa. Dengan adanya motivasi belajar yang dibrikan kepada siswa harapannya dapat untuk meningkatkan prestasi mereka di sekolah.

Motivasi belajar ini diberikan berupa informasi yang dapat memberikan suatu nilai positif dalam meningkatkan prestasi belajar mereka.Bagi mereka yang mempunyai suatu motivasi prestasi dalam belajar akan membangun suatu aktivitas yang positif. Disini akan diberikan suatu informasi mengenai bagaimana meningkatkan motivasi dalam belajar yang akan lebih jelas dijabarkan dihalaman-halaman depan.

Dengan demikian, sangat diperlukan adanya peran aktif guru dan orang tua maupun bagi setiap pemerhati pendidikan dalam membangun motivasi belajar peserta didik diamana pun berada berada demi tercapainya tujuan pendidikan, baik tujuan pendidikan nasional maupun tujuan pendidikan islam.

Berdasarkan hasil pengamatan di MIN Kilongan Permai, Luwuk, Sulawesi Tengah, diperoleh gambaran bahwa dengan adanya kegiatan belajar kelompok yang sering dilakukan oleh beberapa guru yang ada, dapat membangkitkan keinginan belajar peserta didik sehingga mereka tidak pernah mengabaikan waktu untuk selalu mengikuti belajar bersama tersebut.

Ada beberapa hal yang berhubungan dengan anak-anak dan sangat penting untuk diperhatikan bahwa pada anak-anak itu memiliki sifat khas antara lain sebagai berikut :

1. Adanya kolerasi positif yang tinggi antara keadaan jasmsni dan prestasi sekolah.

2. Adanya minat terhadap kehidupan praktis sehari-hari yang kongkret.

3. Amat realistis, ingin tahu, ingin belajar.

4. Menjelang akhir masa ini telah ada minat kepada hal-hal dan mata pelajaran-mata pelajaran khusus.

5. Kira-kira umur 11 tahun anak membutuhkan seorang guru atau orang-orang dewasa untuk menyelesaikan tugasnya dan memenuhi keinginannya

6. Anak memandang nilai (angka rapor) sebagai ukuran yang tepat mengenai prestasi sekolah.

7. Gemar membentuk kelompok sebaya.

Berdasarkan penjelasan tersebut diatas, maka dapat disimpulkan bahwa membentuk kelompok belajar untuk meningkatkan semangat belajar siswa sangatlah penting. Meskipun masih banyak orang yang tidak menggunakan strategi belajar tipe Learning Community tapi harus diakui bahwa tidak orang yang telah melakukannya dan menyajikan hasil yang sangat baik meskipun sebagian dari mereka tidak melaksanakannya dengan efektif dan efisien tapi setidaknya mereka dapat menjadi bukti dan acuan bagi kita bahwa Learning Community merupakan strategi belajar sangat baik untuk dilakukan dan dikembangkan.

Melihat permasalahan yang ada, maka penulis berpikir bahwa sangat penting adanya usaha dalam meningkatkan motivasi belajar siswa dengan menggunakan strategi belajar tipe Learning Community dalam rangka meningkatkan semangat belajar siswa. Berdasarkan hal tersebut, perlu dilakukan penelitian dengan judul "Meningkatkan 
motivasi belajar melalui Learning Community siswa kelas V di MIN Kilongan Permai Luwuk, Sulawesi Tengah."

\section{METODE PENELITIAN}

\section{Jenis Penelitian}

Penelitian ini dilaksananakan di MIN Kilongan Permai Luwuk pada bulan Agustus sampai dengan Desember 2014. Jenis penelitian yang digunakan dalam penelitian ini adalah penelitian deskriptif. Metode penelitian deskriptif adalah salah satu metode penelitan yang banyak digunakan pada penelitian yang bertujuan untuk menjelaskan suatu kejadian. Seperti yang dikemukakan oleh Sugiyono (2011) "penelitian desktiptif adalah sebuah penelitian yang bertujuan untuk memberikan atau menjabarkan suatu keadaan atau fenomena yang terjadi saat ini dengan menggunakan prosedur ilmiah untuk menjawab masalah secara aktual". Sedangkan, Nana Syaodih Sukmadinata (2006) menyatakan bahwa metode penelitian deskriptif adalah sebuah metode yang berusaha mendeskripsikan, menginterpretasikan sesuatu, misalnya kondisi atau hubungan yang ada, pendapat yang berkembang, proses yang sedang berlangsung, akibat atau efek yang terjadi atau tentang kecenderungan yang sedang berlangsung.

Dari kedua pengertian tersebut, dapat dikatakan bahwa metode penelitian deskriptif adalah sebuah metode yang digunakan untuk mendeskripsikan, menginterpretasikan sesuatu fenomena, misalnya kondisi atau hubungan yang ada, pendapat yang berkembang, dengan menggunakan prosedur ilmiah untuk menjawab masalah secara actual. Sumber data adalah segala sesuatu yang dapat memberikan informasi mengenai data. Selama melakukan pengumpulan data, penulis menggunakan beberapa metode yang saling mendukung dan melengkapi. Adapun metode yang digunakan yaitu: a). Observasi pengamatan terhadap kegiatan yang sedang berlangsung (Nana Syaodih Sukmadinata, 2006 ). Metode ini digunakan untuk mengetahui motivasi belajar siswa dengan menggunakan strategi belajar tipe Learning Community.b). Interview (Wawancara) suatu proses tanya-jawab lisan, dalam mana dua orang atau lebih berhadap-hadapan secara fisik, yang satu dapat melihat muka yang lain dan mendengarkan dengan telinga sendiri suaranya, tampaknya merupakan alat pemgumpulan informasi yang langsung tentang beberapa jenis data social, baik yang terpendam (latent) maupun yang memanifes Wawancara yang ditujukan kepada Kepala Sekolah beserta staf pendidik di MIN Kilongan Permai Luwuk untuk mendapatkan informasi tentang bagaimana bagaimana peran guru dalam meningkatkan motivasi belajar siswa. c). Angket (Kuesioner) merupakan teknik pengumpulan data yang dilakukan dengan cara memberi seperangkat pertanyaan atau pernyataan tertulis kepada responden untuk dijawab (Sugiyono, 2011). Metode ini digunakan untuk mengumpulkan data tentang persepsi siswa tentang kompetensi sosial guru akidah akhlak dan data tentang perilaku sosial peserta didik. Hal tersebut diperoleh dari proses penyebaran angket yang berisi beberapa item pertanyaan dan seluruh siswa menjadi responden. 


\section{HASIL DAN PEMBAHASAN}

Selama ini berlaku pandangan bahwa tugas guru mengajar, mendidik, dan tugas siswa belajar. Di berbagai kesempatan kepala sekolah atau guru senantiasa memberi nasehat kepada siswanya bahwa siswa harus belajar. Tugas siswa belajar dan belajar agar diperoleh prestasi tinggi dan lulus ujian. Jika siswa berprestasi dalam ujian maka prestasi sekolah akan meningkat.

Akibat prestasi ujian sekolah dikaitkan dengan prestisi sekolah, maka hampir semua kepala sekolah dan pejabat (Diknas, Gubernur, Bupati) berupaya keras agar semua siswa lulus ujian dan berprestasi dalam ujian nasional. Sekolah yang persentase kelulusannya tinggi dan rangking nilainya tinggi menjadi sekolah berprestasi. Sebaliknya jika persentase kelulusannya rendah atau rangking nilainya rendah merupakan sekolah yang tidak berprestasi. Yang menjadi masalah justru bagaimana meraih prestasi tersebut. Pada umumnya keluar anjuran atau petunjuk "dari atas" bahwa agar prestasi sekolah dapat ditingkatkan maka siswa harus di dril, diadakah jam tambahan atau les, atau siswa disuruh melakukan latihan menyelesaikan soal-soal. Kenyataan menunjukkan bahwa dengan dril atau les singkat, prestasi siswa dalam ujian nasional dapat ditingkatkan dan mutu sekolah juga dapat ditingkatkan.

Pertanyaannya adalah: apakah model "dril", les, mengerjakan soal-soal itu merupakan gambaran siswa belajar? Apakah "keterampilan" dan "kehebatan" siswa dalam mengerjakan soal-soal ujian dapat diterapkan dalam mengatasi permasalahannya? Apakah model dril dalam waktu singkat telah dapat memberi bekal kepada siswa untuk memecahkan permasalahan kehidupannya secara ilmiah?

Psikomotor atau keterampilan tidak dapat dicapai dalam waktu singkat. Keterampilan memerlukan waktu. Semakin banyak jam terbang seseorang, keterampilannya semakin baik dan orang tersebut menjadi lebih profesional. Keterampilan siswa yang perlu dilatihkan adalah menggambar, membuat tabel, grafik, menggunakan alat, merancang kegiatan, menyusun masalah, hipotesis, melakukan eksperimen, mentabulasi data, menganalisis data, hingga ke terampil membuat laporan dan mengkomunikasikannya (ini semua merupakan tuntutan dalam KTSP). Afektif atau sikap merupana suatu pendapat sebelum bertindak, setuju tidaknya siswa terhadap suatu fenomena, atau aturan, menjunjung tinggi kedisiplinan, tenggang rasa, mau menerima saran, bersikap objektif, menjaga kebersihan, dsb. Sikap tidak dapat dibentuk seketika. Proses pembentukan sikap memerlukan waktu, karena diperlukan adanya internalisasi dan proses psikologis seseorang. Orang yang paham dan terampil seringkali dibarengi dengan pembentukan dan perubahan sikap yang positif. Sebagai contoh, Setiap siswa akan dapat mendefinisikan apa itu disiplin (kognitif). Dia mungkin dapat bertindak disiplin misal diajak tepat waktu untuk mengikuti rapat (psikomotor). Tetapi apakah dia selalu bersikap disiplin dalam setiap tingkah lakunya? Jelaslah bahwa mengubah sikap memerlukan waktu, kemampuan dan kemauan seseorang. Pembiasaan, latihan berulangkali, penguatan (reinforcement) sangat diperlukan. Apakah penerapan hukum (menjatuhkan sangsi) diperlukan di sekolah agar sikap dapat ditanamkan? 
Belajar adalah suatu bentuk perubahan dalam diri seseorang yang dinyatakan dalam cara-cara bertingkah laku yang baru berkat pengalaman dan latihan. Tujuan pembelajaran yang diinginkan tentu yang optimal agar dapat mencapai prestasi belajar dengan baik. Untuk itu, metode pembelajaran adalah salah satu hal yang perlu diperhatikan pendidik. Salah satu metode tersebut adalah metode Learning Community, yaitu berbicara dan berbagai pengalaman dengan orang lain, bekerjasama dengan orang lain untuk menciptakan pembelajaran yang lebih baik dibandingkan dengan belajar sendiri. Siswa benar-benar ditempatkan sebagai subjek belajar.

Learning Community merupakan suatu komunitas belajar di lingkungan sekolah di dalamnya berlangsung proses belajar mengajar antara siswa-siswa, guru-siswa, guruguru, guru-kepala sekolah, sekolah-masyarakat. Meskipun definisi ini mudah diucapkan dan dihafalkan, tetapi untuk mengimplementasikannya diperlukan pemahaman dan pengahayatan yang mendalam, bahkan memerlukan reformasi pandangan guru.

Hasil kerja kelompok pada umumnya lebih baik hasilnya daripada kerja secara individual. Ada rasa tanggung jawab kelompok, semua anggota dalam kelompok mempunyai tanggung jawab yang sama. Upaya membangun motivasi belajar bagi anak yang belum mampu dapat diadakan. Menciptakan situasi dan kondisi yang memungkinkan seorang anak belajar dengan anak lainnya. Ada rasa tanggung jawab dan kerja sama antar anggota kelompok untuk saling memberi dan menerima. Ada fasilitator/guru yang memandu proses belajar dalam kelompok. pembelajaran dengan teknik learning community adalah proses pembelajaran yang membiasakan siswa untuk bekerja sama dan memanfaatkan sumber belajar yang ada dilingkungan sekitar, sehingga terjadi komunikasi dua arah yang menghasilkan pengetahuan dan pengalaman baru.

Pembelajaran di dalam kelas dengan teknik learning community, kegiatan pembelajaran dilakukan dalam kelompok-kelompok belajar: siswa yang pandai mengajari yang lemah dan yang tahu memberi tahu yang belum tahu. Masyarakat belajar bisa tercipta apabila ada komunikasi dua arah. Dalam masyarakat belajar, anggota kelompok yang terlibat dalam komunikasi pembelajaran dapat saling belajar. Siswa yang terlibat dalam kegiatan masyarakat belajar memberi informasi yang diperlukan oleh teman bicaranya dan juga meminta informasi yang diperlukan dari teman bicaranya (Nurhadi, dkk;2004:49).

Dengan adanya kelompok belajar maka akan menjadi dorongan atau semangat tersendiri bagi setiap siswa untuk belajar, tidak ada yang merasa tidak memiliki kesempatan untuk mengembangkan diri karna pada prinsipnya learning community atau kelompok belajar merupakan kegiatan saling belajar yang bisa terjadi apabila tidak ada pihak yang dominan dalam komunikasi, tidak ada pihak yang merasa segan untuk bertanya, tidak ada pihak yang menganggap paling tahu, semua pihak mau saling mendengarkan. Setiap pihak harus merasa bahwa setiap orang lain memiliki pengetahuan, pengalaman, atau keterampilan yang berbeda yang perlu dipelajari, diantara peserta kelompok selalu saling melengkapi satu dengan yang lainnya. 
Tugas penting guru pada pendidikan formal di sekolah di antaranya adalah membantu peserta didik untuk mengenal dan mengetahui sesuatu, terutama memperoleh pengetahuan. Dalam pengertian konstruktivisme, pengetahuan itu merupakan "proses menjadi”, yang pelan-pelan menjadi lebih lengkap dan benar. Pengetahuan itu dapat dibentuk secara pribadi dan peserta didik itu sendiri yang membentuknya.

Peran guru atau pendidik adalah sebagai fasilitator atau moderator dan tugasnya adalah merangsang atau memberikan stimulus, membantu peserta didik untuk mau belajar sendiri dan merumuskan pengertiannya. Guru juga mengevaluasi apakah gagasan peserta didik itu sesuai dengan gagasan para ahli atau tidak. Sedangkan tugas peserta didik aktif belajar, mencerna, dan memodifikasi gagasan sebelumnya. Dalam KTSP dianut bentuk pembelajaran yang ideal yaitu pembelajaran peserta didik aktif dan kritis. Peserta didik tidak kosong, tetapi sudah ada pengertian awal tertentu yang harus dibantu untuk berkembang.

Metode belajar tipe Learning Community untuk meningkatkan motivasi belajar siswa. Dalam setiap kegiatan belajar tentunya tidak akan bisa terlepas dari peran tenaga pendidik atau guru. Dalam kegiatan kelompok belajar, khususnya pada siswa sekolah dasar tentunya sangat membutuhkan peran guru agar kegiatan belajar dapat berlangsung dengan terarah. Selain itu, guru juga akan menjadi penentu berhasilnya kegiatan kelompok belajar tersebut dengan terus mengawasi setiap kegiatan para siswa yang aktif didalamnya. Dengan demikian, hal tersebut akan memudahkan guru untuk melakukan evaluasi hasil pembelajaran.

\section{KESIMPULAN DAN SARAN Kesimpulan}

Berangkat dari sebuah permasalahan yang penulis angkat sebagai judul karya ilmiah ini dengan beberapa teori, dan dengan mengadakan penelitian secara deskriptif untuk mendapatkan data yang dapat dijadikan bukti nyata dari suatu pernyataan yang diajukan kemudian berdasarkan penelitian serta analisis dari penulis yang ada, maka pada bagian akhir dari penulisan ini dapat diambil suatu kesimpulan bahwa belajar adalah suatu bentuk perubahan dalam diri seseorang yang dinyatakan dalam cara-cara bertingkah laku yang baru berkat pengalaman dan latihan. Tujuan pembelajaran yang diinginkan tentu yang optimal agar dapat mencapai prestasi belajar dengan baik. Untuk itu, metode pembelajaran adalah salah satu hal yang perlu diperhatikan pendidik. Salah satu metode tersebut adalah metode Learning Community atau kelompok belajar, yaitu berbicara dan berbagai pengalaman dengan orang lain, bekerjasama dengan orang lain untuk menciptakan pembelajaran yang lebih baik dibandingkan dengan belajar sendiri. Siswa benar-benar ditempatkan sebagai subjek belajar.

\section{Saran}

Dalam kegiatan kelompok belajar, khususnya pada siswa sekolah dasar tentunya sangat membutuhkan peran guru agar kegiatan belajar dapat berlangsung dengan terarah. Selain itu, guru juga akan menjadi penentu berhasilnya kegiatan kelompok belajar tersebut dengan terus mengawasi setiap kegiatan para siswa yang aktif 
didalamnya. Dengan demikian, hal tersebut akan memudahkan guru untuk melakukan evaluasi hasil pembelajaran.

\section{DAFTAR PUSTAKA}

Djamarah. 2005. Strategi Belajar Mengajar. Jakarta: Rineka Cipta

Hamalik, O 2004. Proses Belajar Mengajar. Bandung: Bumi Aksara

Nana Syaodih Sukmadinata. 2006. Metode Penelitian Pendidikan. Bandung: Rosdakarya.

Nurhadi, dkk. (2004). Pembelajaran Kontekstual(contextual teaching and learning/ CTL) dan Penerapannya Dalam KBK. Malang: UM press

Ngalim Purwanto, Prinsip-Prinsip dan Teknik Evaluasi Pembelajaran, Bandung: Remaja Rosdakarya.

Lexi J. Moeleong. 2006. Metodologi Penelitian Kualitatif. Bandung: Remaja Rosdakarya.

Sugiyono. 2011. Metode Penelitian Pendidikan "Pendekatan Kuantitatif, Kualitatif dan R\&D”. Bandung: Alfabeta.

Arikunto Suharsimi.1993. Manajemen Pengajaran Secara Manusiawi. Jakarta: Rineka Cipta. 